Soccer \& Society

\title{
From Mitropa Cup to UEFA Cup: the role of UEFA in the establishment of a European scale in football, 1927-1972
}

\section{Philippe Vonnard}

To cite this article: Philippe Vonnard (2019) From Mitropa Cup to UEFA Cup: the role of UEFA in the establishment of a European scale in football, 1927-1972, Soccer \& Society, 20:7-8, 1025-1040, DOI: 10.1080/14660970.2019.1680501

To link to this article: https://doi.org/10.1080/14660970.2019.1680501

\section{曲 Published online: 22 Oct 2019.}

Submit your article to this journal $₫$

ЏII Article views: 18

Q View related articles $\widetilde{ }$

View Crossmark data $\asymp$ 


\title{
From Mitropa Cup to UEFA Cup: the role of UEFA in the establishment of a European scale in football, 1927-1972
}

\author{
Philippe Vonnard
}

Institut des sciences du sport de, l'Université de Lausanne (ISSUL), Lausanne, Switzerland

\begin{abstract}
Since the 1920s, many European exchanges began to exist in the domain of football. However, it was during the 1950s that a European scale was established primarily due to the creation of UEFA (Union of European Football Associations) in 1954, which quickly organized the first European tournament in the game's history- The European Champions Clubs' Cup. The present essay argues that Europeanization of the game has to be understood in a long-term perspective. The papers examines the creation and development of three competitions as key defining events, which represented different stages of the Europeanization of the game: Mitropa Cup (created in 1927), European Champion Clubs' Cup (created in 1955) and UEFA Cup (created in 1971). Thus, afocus on these cases can help us better understand the background of the Europeanization of the game which happened during the 1990s.
\end{abstract}

\section{Introduction}

In 2015, Olli Rehn, Finnish president of the European parliament, noted in an interview, 'When I was kid, I discovered - and felt - Europe through football! My political vision developed many years later.' ${ }^{\prime 1}$ In his own words, attending or watching on television the European football competitions enabled him to become a European.

Over the last ten years, the European tournaments in football have increasingly been studied. Much of the research focus on the stakes behind the creation of regional tournaments like the Mittel-Europa (Mitropa) Cup, ${ }^{2}$ the Latin Cup ${ }^{3}$ or the Balkan Cup, ${ }^{4}$ as well as the competitions created by Union of European Football Associations (UEFA) such as the European Champion Clubs' Cup (ECCC) ${ }^{5}$ and the International Youth Tournament. ${ }^{6}$ Some studies have also provided an overview of the European Championship for Nations. ${ }^{7}$ These works have helped us better understand the development of the European scale in football. Taking a step forward in understanding of the Europeanization of football as a connected process involving various countries and associations, Jürgen Mittag has provided a general overview of the European competitions from the Mitropa Cup to the Champions League (which replaced the European Champion Clubs Cup in 1991). ${ }^{8}$

Inspired by this step towards writing comparative and comprehensive histories, and following my preliminary reflections on the UEFA's early history, ${ }^{9}$ in this essay I examine what the creation of the UEFA in 1954 entailed in the history of European competitions, especially its role in the creation of European competitions for clubs. Two aspects of my definition of a European tournament are: it has to be a competition that brings together clubs from all parts of Europe - from Russia (east) to Ireland (west) and from Sweden (north) to Cyprus (south); and it must comprise the top clubs in domestic championships across Europe. 
This article follows a chronological frame with three sections. Here, I focus respectively on the Mittel-Europa (Mitropa) Cup - the main supranational competitions organized during the interwar period; the European Champions Clubs' Cup (ECCC) - the first competition created by UEFA; and the UEFA Cup (UC) - the third main tournament which, launched by UEFA (in fact a takeover of the Inter-Cities Fairs Cup), opened the door for the creation of UEFA Champions League twenty years later. In addition to expanding our knowledge of the creation and development of these tournaments, this article will analyse the similarities and differences between these tournaments concerning their claim to be considered 'European' tournaments. Based on documents collected from the rich UEFA archives, this will help to retrace the development of the European competitions and more generally to understand UEFA's role in the process.

\section{Playing at the regional scale: the Mitropa Cup}

It is widely known that modern football originated in England and spread to the Continent in the late nineteenth and early twentieth centuries. The promoters of the game in national contexts soon intended to create international exchanges. ${ }^{10}$ Teams from England - seen on the Continent as the 'master of the game' - were invited to the Continent, like the Surrey Wanderers Football Club tour in Switzerland in 1901. Then, teams from the Continent also began to play against each other, as exemplified by the Racing Club de Paris travelling to Prague in the same year. International matches began to be played in the 1900s. Before 1914, the national team of Belgium had already played 45 games, Hungary 40 and Sweden 29. ${ }^{11}$ French historian Paul Dietschy has explained the rapid growth of these international matches - which were still played principally between neighbours - by 'the low cost and ease of transport, cultural affinity, and the desire to establish a regular relationship so as to assess the progress of one's national team. ${ }^{, 12}$ Following the example of the British championship (played between the national teams of England, Northern Ireland, Scotland and Wales) founded in 1885 , football promoters sought to create superregional competitions. FIFA's early idea of launching a world championship failed, but smaller tournaments like the Van der Straeten Ponthoz Cup took place from 1900 to 1907 (between teams from Belgium, England and the Netherlands) or the Pyrenean Cup was played from 1910 to 1914 (between clubs from France and Spain).

The interwar period was the game's first period of democratization. The stranglehold of elites on the game's organization moderated as politicians across Europe began to see the people's game as an effective means of reinforcing national identity and showing their strength in international relations. ${ }^{13}$ Thus, the number of international games (for nations and clubs) increased significantly. The newspapers of the period indicate that annual games - for instance the Racing Club de Paris versus Arsenal ${ }^{14}$ - or tours - for example those by the best Viennese teams - were organized on a regular basis. Moreover, many tournaments were held, notably in Brussels or Paris. These championships were generally organized over three or four days and involved between three and five teams. Among the more important tournaments was the Cup of the Nations held in Geneva in 1930 comprising 10 clubs from 10 different countries, which the German sport newspaper Kicker named the 'Genfer Kleine Olympiade'. Another important football tournament was held in 1937 at the Paris World Fair, which grouped eight professional teams from eight different countries. The tournament was won by Bologna AFC. ${ }^{15}$ Earlier, this team had also participated in the most important competition for clubs in the interwar period: the Mittel-Europa (Mitropa) Cup.

The idea of an important club competition unfolded in the general context of two main processes in the development of football: the creation of the World Cup and the legalization of professionalism. In regard to the creation of the World Cup, Grégory Quin has shown the operation of two opposing ideas inside FIFA. On the one hand, the main leaders of 'Danubian football' (Austrian, Czech, Hungarian and Italian) wanted to create a European championship. On the other hand, French leaders such as Henri Delaunay and Jules Rimet wished to organize a world championship based on their universalist point of view. ${ }^{16}$ If the second option was chosen by the delegates at the 1928 FIFA General Assembly, ${ }^{17}$ the first was nevertheless realized for the clubs. Secondly, the 
legalization of professionalism during the 1920s in Austria, Czechoslovakia and Hungary encouraged the creation of a new major international tournament, because the clubs needed additional income to pay the players. International games, or tours abroad, seemed to be the best source of generating money. Paul Dietschy quotes an article from the Italian newspaper, La Stampa, which indicated that for Italian teams 'matches between the strongest European teams are indeed likely to produce significant income. ${ }^{18}$ This idea to earn money through the new competition is revealed by the fact that a division of the game receipts (between the clubs which played at home and the club which played abroad) was adopted by the organizational committee of the match(es).

Initial discussions about the creation of a tournament for clubs and/or nations took place in 1925 and 1926, but it was during a meeting in Venice in mid-July 1927 that Austrian, Italian, Hungarian, Czech, Hungarian and Swiss representatives decided to create the competition. On the one hand, they decided to organize two competitions, one for clubs (Mitropa Cup) and one for nations (Central Europe Cup). On the other hand, the international tournament grouped national teams from Austria, Czechoslovakia, Italy, Hungary and Switzerland that faced each other in home and away matches with direct elimination. The competition for the clubs grouped teams from Austria, Czechoslovakia, Hungary and Yugoslavia.

It is important to note that each competition had a different character. Switzerland did not participate in the club tournament principally because professionalism was not officially permitted there yet. Yugoslavia opted out of the tournament for nations perhaps due to the weakness of the national team (which still played mostly against its neighbours - Bulgaria, Greece and Rumania). However, the participation would change, and in 1929 the teams from the strong Italian championship replaced Yugoslavian clubs. Sporting and political reasons - notably Mussolini's intention to develop his influence in Central Europe - could explain this change. ${ }^{19}$

The Mitropa Cup's importance increased each year and, by the middle of the 1930s, it was established as a coveted championship for clubs in Central Europe. The competition had two legs (one game away, one game at home) and the team with maximum points won. In 1934, each country sent four representatives, which required establishing an additional elimination round. Two years later, the number of clubs continued to increase with the participation of Swiss teams. As the Swiss

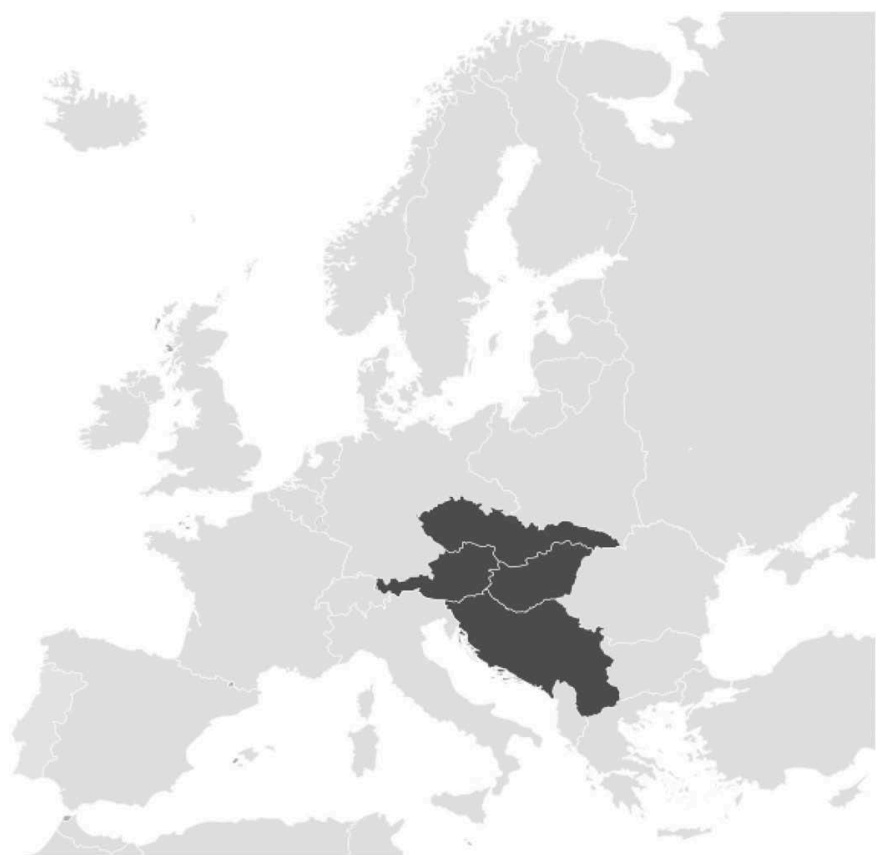

Map 1. National associations which participated in the Mitropa cup in 1927. light grey: associations which did not participate; dark grey: associations which had two clubs in the competition. 
national association had legalized professionalism two years before, ${ }^{20}$ the best team of the Swiss league saw a good opportunity in the Mitropa Cup to receive additional income that could help to provide for the increase of their fees. The increased number of participants led to the creation of a preliminary round in which the four Swiss clubs faced two Austrian teams, one Hungarian team and one Czech team. The year 1936 marked the high point of the Mitropa Cup. In fact, over 40 games were played in approximately three months (from June to September) that year.

In 1937, Romanian and Yugoslavian teams joined the Cup. However, the event was trapped in the political context that grew ever more tensed and prevailed throughout the Continent. First of all, Austrian teams pulled out on account of the Nazi invasion of Austria (the Anschluss). Furthermore, in 1938 Swiss clubs withdrew from the competition citing reasons of financial hardship and lack of convincing results. Subsequently, the 1938 and 1939 tournaments were shortened and limited to the months between June and August. Although well-organized with a lot of public appeal, the Mitropa Cup in 1940 could include only eight clubs from Hungary, Romania and Yugoslavia. This was the end of the tournament, and it was ultimately suspended for over fifteen years.

According to Matthias Marschick, Mitropa Cup was a popular competition. ${ }^{21}$ Moreover, the popularity of the tournament transcended geographical boundaries because sport newspapers from Belgium (La Vie sportive), France (L'Auto), Germany (Kickers) reported on the main games. ${ }^{22}$ However, Mitropa cup remained essentially regional in character, and if some clubs (like Racing club de Strasbourg in 1939) wished to participate in the competition, the associations from stronger West European countries (notably from Belgian, Dutch, French, Portuguese and even Swiss associations) objected and asked them to create a separate competition. ${ }^{23}$ Otherwise, the criterion for participation was not altogether stable. Actually, although Italian and Czech representatives in the Cup were the teams that achieved the top positions in their national championship, this was not always the case for Hungarian teams, let alone for Austrian teams. Around 40 clubs from eight countries participated (in total) in the tournament, a number that reveals well the importance of this regional scale tournament and confirms Quin's view of the 1920s and 1930s as the 'Golden Age of Regional exchanges.' ${ }^{24}$ Thus, while Mitropa

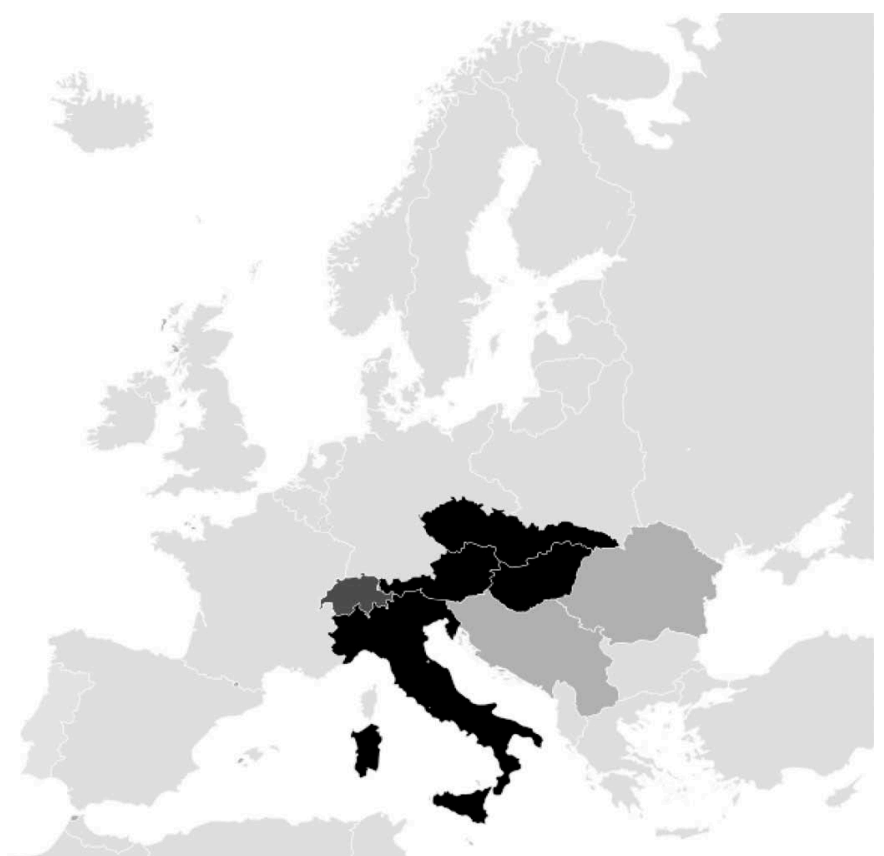

Map 2. National associations which participated in the Mitropa Cup in 1937. light grey: associations which did not participate; grey: associations which participated (one club); dark grey: associations which had two clubs in the competition. 
cup can rightly be seen, as Mittag indicated, as the strongest preliminary basis for establishing a European tournament for the clubs, ${ }^{25}$ it cannot be really considered as a truly European tournament in view of the two main criteria we have set for it in the introduction.

\section{Europe as a new playground: the European Champion Clubs' Cup}

After the end of the Second World War, football administrators and journalists resumed discussing the idea to recreate supranational competitions for clubs. The first international cup was organized in 1948 , which had to be stopped soon with the escalation of the Cold War. ${ }^{26}$ In 1949, a mini-championship called the Latin Cup was played between one club each from France, Italia, Portugal and Spain was created. ${ }^{27}$ One year later, the Festival of Britain allowed many Continental clubs (mainly from Western blocs) to cross the Channel and play against English teams. In 1952, the German coach of the Grasshopper Football Club (Zurich), Willy Treml, developed the idea of a superregional cup. ${ }^{28}$ Known as the 'Grasshopper Cup', the tournament followed a closed geography compared to the Mitropa cup (a German and French clubs replaced the Czech and Hungarian representatives). It lasted from 1952 to 1957 and saw the participation of six teams from six different countries. Finally, in the middle of the 1950s, the Mitropa Cup was resumed. ${ }^{29}$

These connections permitted the progressive rebirth of regular football exchanges of the interwar period. However, the time seemed more favourable for the establishment of an idea which had already been developed by some football actors during the 1930s: creating a European competition, which would include, contrary to the Mitropa Cup, clubs from four parts of the Continent. In addition to the new international context created by the death of Stalin, which provided opportunities to recreate East-West connections in various fields (academia, culture, sciences and sports) in Europe, five main reasons explain this new possibility. Firstly, the growth of civil airlines - which however had a tragic consequence for the football community with the Superga Disaster of $1949^{30}$ - facilitated travels throughout the Continent. Secondly, the coming of floodlights extended the possibilities of organizing games, notably during the night in autumn and winter and also late in the evening in summer. Thirdly, some journalists pointed out that footballers should avoid playing in summer as they would be tired after a long season of battle in the domestic league and in several friendly games played abroad. ${ }^{31}$ They suggested it could be better to play in the cooler seasons of autumn or winter and to replace the international mid-week friendly games with an international competition. Fourthly, the new initiatives taken to promote professionalism in many European countries meant that players were available to play mid-week, but also required the clubs to find new financial resources. This also encouraged the development of a more ambitious competition. Finally, some football administrators believed that the formation of a European body in June 1954, named UEFA in October, ${ }^{32}$ could help in the creation of the European tournament. One of the main promoters of UEFA, the Italian Ottorino Barassi, had been speaking of this kind of idea to the press since the beginning of the decade. ${ }^{33}$

The strongest plan aiming to organize a European championship for clubs came from French journalists from L'Equipe. ${ }^{34}$ On 15 December 1954, Gabriel Hanot suggested the idea after a friendly match in which the English team Wolverhampton Wanderers beat the Hungarian team Hondved. ${ }^{35}$ Hanot, a veteran journalist, was also an activist working on the development of French alias European football. With the aid of his experienced colleagues, including Jacques Ferran, and Jacques Ryswick, he developed the idea with full support from l'Equipe, a newspaper with significant financial capacity and a wide network of foreign correspondents, and its owner, Jacques Goddet, ${ }^{36}$ who thought that promoting such an innovative tournament would bring financial gains for his newspaper. While many clubs around Europe (like Anderlecht, Real Madrid, Servette Geneva, Stade de Reims or Voros Lobogos) were quick to show interest in the idea, French journalists failed to convince UEFA to start such a tournament. In fact, during its first General Assembly held in Vienna in March 1955, the delegates of UEFA refused to give consent to any such competition. ${ }^{37}$ Without getting frustrated by UEFA's reluctance, French journalists continued consulting club directors and federation bosses from every corner of Europe, who finally selected 15 clubs and invited them to a meeting in Paris on April 3-4, 1955. In this meeting, 
rules were adopted, an organizing committee was appointed and the first round of the European Cup was decided upon. Chelsea-Djurgarden; Real-Servette; Milan-Sarrebruck; Essen-Hibernian; Voros Lobogos-Anderlecht; Reims-Copenhagen; Rapid-Holland Sport; Partizan-Sporting Lisbon were to face each other in the round of 16 of this first European Cup.

UEFA and FIFA's main leaders understood that it was not possible to let this private enterprise continue because it could challenge their power over the management of the game. Many debates on the championship took place at meetings of the Emergency Committees of FIFA and UEFA between 6 and 8 May in London. The members of both organizations finally decided to authorize the tournament under certain conditions (notably that UEFA had to organize it). ${ }^{38}$ On 1 June 1955, the Union officially resumed control of the tournament, which would later be called the European Champion Clubs' Cup (ECCC). ${ }^{39}$

The competition's format was similar to that of the Mitropa cup and the first ECCC saw a satisfactory popular success. According to the 1954-5 report of the UEFA General Secretary, 800,000 spectators attended the 29 matches during the event (an average of 28,000 fans per game).$^{40}$ In view of this success, UEFA decided to organize the ECCC again the following year. This effected two major changes in the original plan of the French journalists. First, it enlarged the European dimension of the competition by inviting Bulgaria, Czechoslovakia and East Germany - countries that had not initially been invited by the journalists of L'Equipe - to participate in the tournament. ${ }^{41}$ Secondly, French journalists had chosen clubs for their prestige (for instance, Real Madrid and Partizan Belgrad) and for personal relations (for instance, some of them had close connections with the president of Servette Geneva and Stade de Reims). If UEFA's top leaders decided to keep the teams selected by L'Equipe for the first edition, for the second one they included only the champion of the national league of respective countries. This decision created a direct link between the national and European competition and broke the arbitrary choice of the private organizers.

In the following years, the success of the ECCC increased substantially. In 1956-7, the number of participating teams reached 22 , which required the establishment of a preliminary round. At the

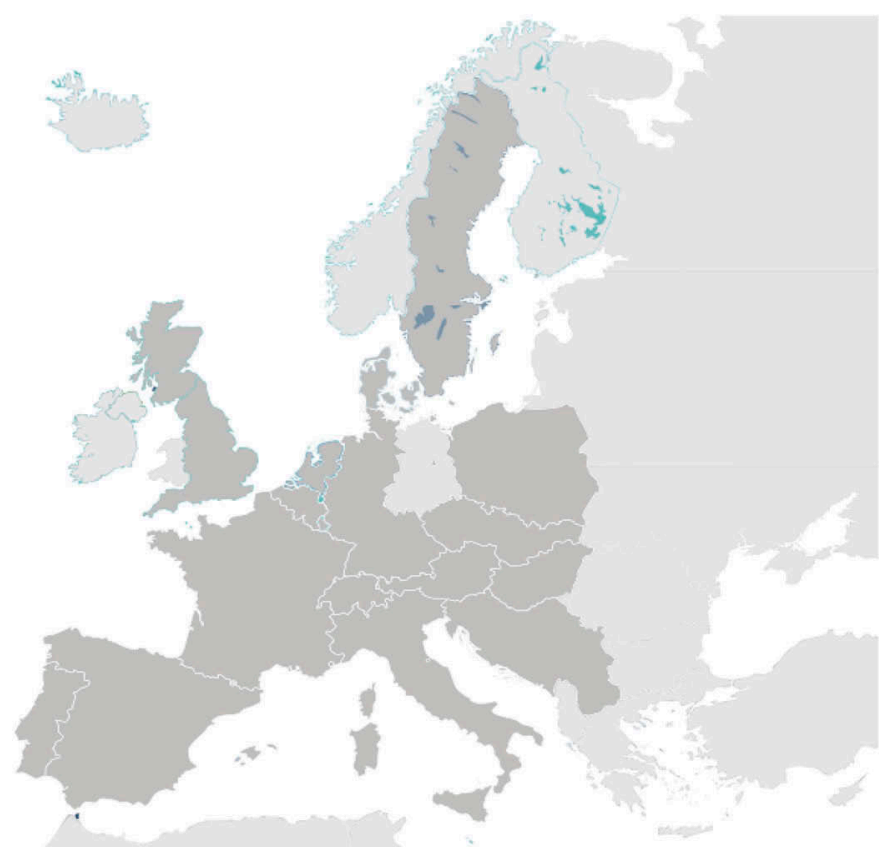

Map 3. National associations which participated in the first ECCC. pale grey: associations which did not participate; grey: associations which participated (one club). 
beginning of the 1960s, all the 33 national associations affiliated to UEFA sent their champions to compete in the tournament. Furthermore, the attendance increased to around 35,000 for the season 1964-65. ${ }^{42}$ It was a crucial step forward in the establishment of the European scale in football.

Moreover, the competition had a huge impact on the governance and structure of UEFA and its future plans. On the one hand, the European Champion Clubs' Cup offered to the Union a new important task: to start a competition for national teams. Although the first draft statutes of UEFA included the idea to organize a European Championship for Nations, the project was rejected by the first UEFA General Assembly held in Vienna in March 1955. In fact, the members of the Executive Committee (such as Henri Delaunay or José Crahay) who would later develop European competitions were a minority on UEFA's board. The takeover of the European Cup changed this situation. One year later, the Union ssumed control of the organization of the International Youth Tournament, which, started in 1948 by Stanley Rous, came under the authority of FIFA from 1949. ${ }^{43}$ At the end of the 1950s, the project of a European Championship for Nations was accepted by the UEFA General Assembly, leading to the commencement of the European Nations' Cup from 1960. As a result, the administrative bodies of the Union grew smartly. In 1958, UEFA was composed of seven permanent commissions dealing with different topics on European football (television, youth football, competitions, finance and so on). Ten years later, UEFA had 15 permanent commissions and the new version of its Statutes now spanned more than 20 pages. The organization of two major European competitions undoubtedly encouraged the creation of a headquarters in Bern in 1960. It gave more legitimacy to UEFA amongst international football actors and allowed more autonomy from FIFA. ${ }^{4}$

On the other hand, the 1955 European Champions' Club competition offered UEFA new financial possibilities. UEFA, without having any budget at its inception, began to receive a 1 per cent levy on the general receipts for each match and 5 per cent for the final. ${ }^{45}$ This new source of financial support notably helped to sponsor youth football - especially within small associations. From 1957 a special account for this purpose was created from the finances of the European Champion Clubs' Cup. ${ }^{46}$ In addition, a new actor entered the game: television. In fact, since the early 1950s, national television organizations began to take active interest in broadcasting football matches. With ten games broadcast live, the 1954 World Cup was at the core of the first exchanges of the new Eurovision network founded that year by the European Broadcasting Union (EBU) ${ }^{47}$ With the successful organization of the first European Champions' Club Cup in 1955, the EBU showed interest in relaying the event. ${ }^{48}$ In March 1956, a meeting was organized between UEFA's board members and a delegation from EBU. After much discussion, the leaders agreed to build partnerships between the two entities in the light of their respective interests' ${ }^{49}$ As the idea was in the air and the first experience of live broadcasting on the Eurovision network of the first final of the ECCC was considered to be a success by journalists, ${ }^{50}$ football leaders were still reluctant to encourage television because they thought that it could reduce attendance in the stadium (notably during the winter or on rainy days). If a contract was signed between UEFA and EBU in 1961, it was only in 1968 that a long-term contract (four years) for the broadcasting of the ECCC final was signed. ${ }^{51}$ It was important for UEFA because the body received one million Swiss francs from EBU for the live broadcast of the game. For the play-off, the Union also obtained 25 per cent of the total amount paid by national television to broadcast a game. ${ }^{52}$ The television rights from the ECCC were UEFA's first major income and represented around 30 per cent of its total income. ${ }^{53}$ This amount permitted the Union to develop its policy for development of the game. Considerable reserve funds were created thanks to the television income and were used to support the development of youth and amateur football and to organize training for coaches and referees.

The European Champions' Club Cup also offered opportunities to create new links between the confederation's members. In fact, all the European countries were quick to get involved in the tournament. In the period of East-West rivalry in Europe, with problems ranging from visa and travel difficulties to tension on the pitch, the European competition organized by UEFA fostered 
East-West connections. ${ }^{54}$ This supported the position of the members of UEFA's board who had tried, since its foundation, to limit the impact of international politics on their organization. ${ }^{55}$

The creation of the European Champions Clubs' Cup by UEFA in 1955 marked a major change in the history of European. Firstly, it was a truly European tournament because it involved all of the national associations affiliated to UEFA, thereby making the Cup an enjoyable experience for the European audience as a whole. Other examples of pan-European unity through culture in this period were the coverage by Eurovision in Western Europe and Intervision in Eastern Europe. Furthermore, as the apex body of European football represented by national associations of its member countries, UEFA established a precise criterion for participation: national champion in its domestic league. This decision - which in the first years of the tournament was occasionally challenged by some associations, but nevertheless always respected - had an impact on the national league itself because it created a healthy competition both at national and European level. Finally, the schedule of the tournament from September to May brought parity in the football calendar of European countries.

\section{The European scale in place: from the Fairs Cup to the UEFA Cup}

During the first half of the 1960s, UEFA was preparing to create other competitions and launched the European Winner Clubs' Cup (EWCC) comprising the winners of national championships. This tournament compelled the national associations to start relevant national level cups for sending their representative teams to the tournament. The joint success of ECCC and EWCC gave further fillip to the idea of organizing a Continental tournament among various stakeholders of the game including clubs, journalists and even political organizations (such as the European community). ${ }^{56}$ In 1967, a round table meeting was held in Monaco with 25 clubs from 11 countries, many journalists and also the vice-president of UEFA, José Crahay (who did not represent UEFA but came in his personal capacity). ${ }^{57}$ While the question of European competitions was widely

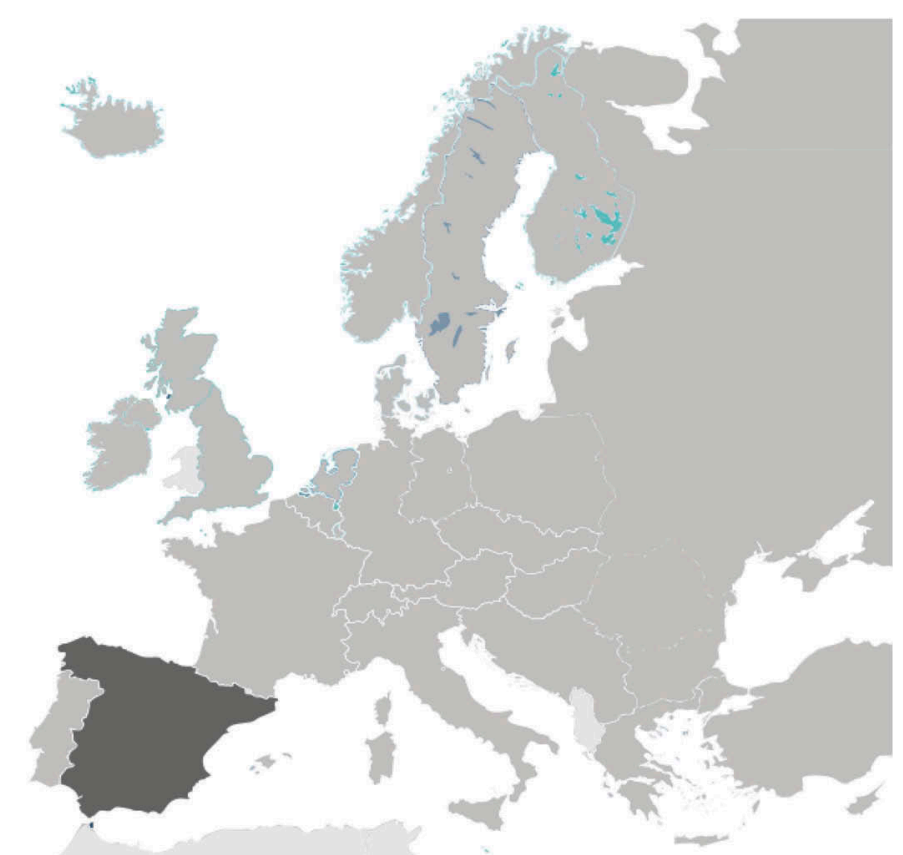

Map 4. National associations which participated in the ECCC in the season 1966-1967. pale grey: associations which did not participate; grey: associations which participated (one club); dark grey: associations which had two clubs in the competition (the previous winner was directly qualified for the next ECCC). 
discussed in the meeting, the idea of having more than one representative team per country in the European Champions Clubs' Cup became a major issue of debate, bringing back to focus another major tournament founded in 1955 - the Inter-Cities Fairs Cup.

This competition was established at the same time as the ECCC by three distinguished European football administrators: Ottorino Barassi, president of the Italian Football Federation; Stanley Rous, secretary of the British Football Association; and Ernst Thommen, president of the Swiss Football Association, all influential position-bearers within FIFA. ${ }^{58} \mathrm{~A}$ unique feature of the Fairs Cup was that the competition did not invite clubs but rather city-based football teams (for instance, London XI which was comprised players from different London clubs). In fact, as its name clearly stated, it was about gathering the cities that organized major international fairs with single championships. In his memoirs, Stanley Rous recalls the creation of the championship and argues that the main objective was to create a football championship which would contribute to fostering friendship among nations. To this effect, an event which convened the cities that organized international commerce expos was advantageous because it could establish new contacts between politicians and businessmen from various continental countries. ${ }^{59}$ Political and economic objectives therefore predominated in organizing the event.

The Fairs Cup was the outcome of a meeting organized in Basel at the insistence of Ernst Thommen on 18 April 1955. The cities of Basel, Cologne, Copenhagen, Frankfurt, Lausanne, Leipzig, London, Vienna and Zagreb, and three clubs (Barcelona, Birmingham and Inter Milan) sent their delegates, who decided to start a tournament. ${ }^{60}$ In contrast to the project of L'Equipe, FIFA and UEFA granted it swift recognition and did not interfere in its management. ${ }^{61}$ However, there were many leading football personalities of the time, who used to be present at the annual general assemblies that managed the Cup, such as the German Joseph (Peco) Bauwens or the Swiss Gustav Wiederkehr. ${ }^{62}$

The first Fairs Cup was a little chaotic, considering that it lasted almost three years and some cities withdrew during the championship (Cologne and Vienna). ${ }^{63}$ Conversely, the second round lasted two years and seemed to develop with greater ease. However, as Jacques Ferran has stated: 'while the club as such was strong, the city itself represented nothing ${ }^{64}$ Ferran's conclusion was not fortuitous, and this was probably the reason why the Fairs Cup committee changed the championship's form in the early 1960s. Henceforth the competition took place in just one season and teams competed against each other following the play-off model of UEFA's competitions. Contrary to the European Champion Clubs' Cup, the Fairs Cup was not limited to one club per country, and national associations could send two, three or even four representatives to the competition. Thus, over the years, the number of teams increased and reached nearly 60 at the end of the $1960 \mathrm{~s}$. The Fairs Cup became the one of the most important European championships of its time even though the average attendance was less than in the European Champion Clubs' Cup; the 1966-7 UEFA general secretary's report indicated that the average crowd per ECCC match was around 27,972 against 15,820 for the Fairs Cup. ${ }^{65}$

However, this rapid growth of the tournament became problematic because of the process of selecting participating teams. To participate in the competition, the club had to propose its candidacy - with agreement of its national association - which was considered by the annual General Assembly of the Fairs Cup. ${ }^{66}$ This arbitrary process of selection gradually came to be questioned in the $1960 \mathrm{~s}^{67}$ To respond to this criticism, national associations (like Scotland and Spain) urged UEFA to take control of the competition. This was also agreed by UEFA's board itself. Indeed, the Union now led the game's European policy (training for referees and coaches, subsidy policies for participation in junior tournaments, agreement with EBU to broadcast matches, the implementation of multiple European championships, etc.). That is why, in the mid-1960s, UEFA's main leaders considered taking over this important European tournament. Finally, during the 1966 UEFA General Assembly, it was decided that the Union would resume the Fairs Cup. ${ }^{68}$ Nevertheless, it took some years before the body officially reinstated it because many clubs were reluctant to make this shift (which appeared as a transfer of power).

Taking over the organization of the cup was important for UEFA because it undoubtedly reinforced its power on the regulation of the game at European scale, a situation that helped the 


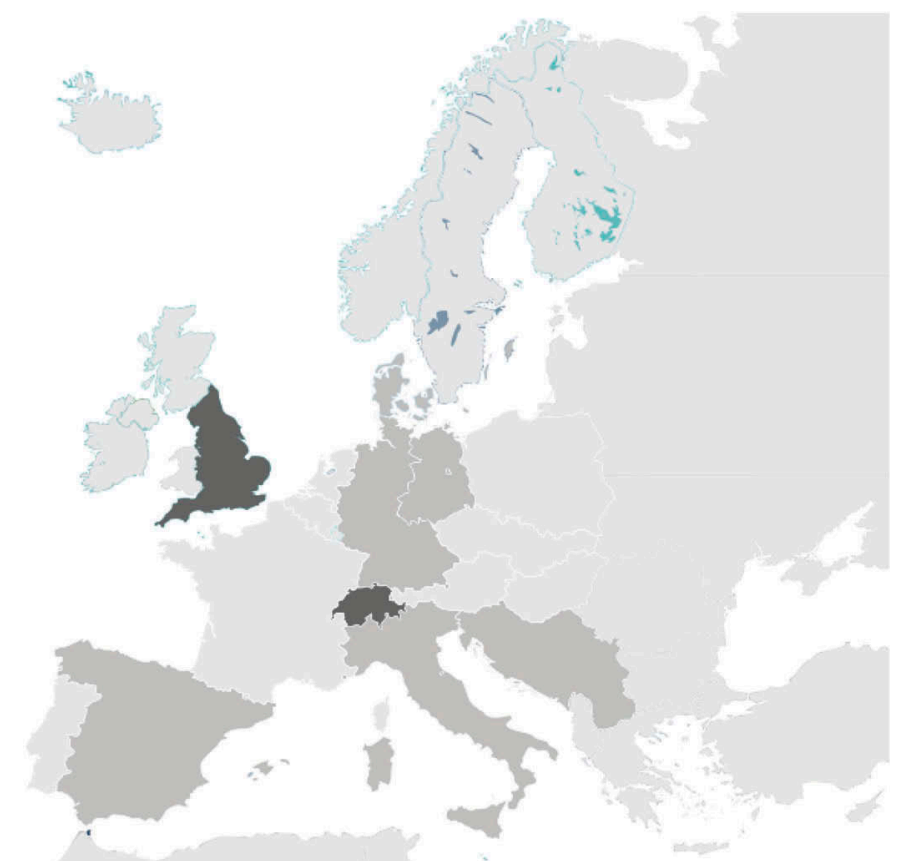

Map 5. National associations which participated in the first Fairs Cup. pale grey: associations which did not participate; grey: associations which participated (one club); dark grey: associations which had two clubs in the competition.

Union to control numerous other projects developed by journalists or by non-sport actors, during the 1960s. ${ }^{69}$ In the early 1970s, the Union finally formed a committee to manage the transition. The delegates decided to change the name of the Cup to the UEFA Cup, a symbolic gesture that gave the Union additional legitimacy. Yet, the UEFA Cup nevertheless remained problematic for the Union in comparison to ECCC and EWCC. In fact, some countries had often two, three or four clubs engaged in the competition. To regulate this, UEFA connected the Continental tournament with outcomes of the national championship. Thus, it was decided that the second, third or fourth of the domestic championship would qualify for the UEFA cup. However, with this decision UEFA opened a new era when it allocated participation quotas to different countries depending on the quality of their domestic championships (for example, England had the right to enter four participants while Albania could enter just one). Thus, it implied the beginning of a formal hierarchy of 'big' and 'small' nations and championships in European football.

In the beginning of the 1970s, the European scale in football was strongly established with UEFA organizing all three major competitions. With the creation of UEFA Cup, the European dimension of the competition was reinforced. In fact, the number of participants, nearly 60 , which came from around 30 countries, offered numerous possibilities to organize European games. Thus, the football season began to be played from September to May at national and European levels. The mutual cooperation of UEFA and national associations was a necessary precondition for efficiently running these European tournaments and ensuring smooth telecast of matches in tandem by Eurovision and Intervision. Moreover, the competition broadened the truly European battle being played in national championships. The UEFA Cup added more value to second, third and even fourth place in national championships, which would be a gateway to Continental championships. Thus, its creation reinforced the dramatization of the domestic league and created a 'race for Europe'. However, the creation of a difference between the 'big' and the 'small' championships and nations opened the gates of a new era which would be materialized by the creation of UEFA champions League twenty years later. 


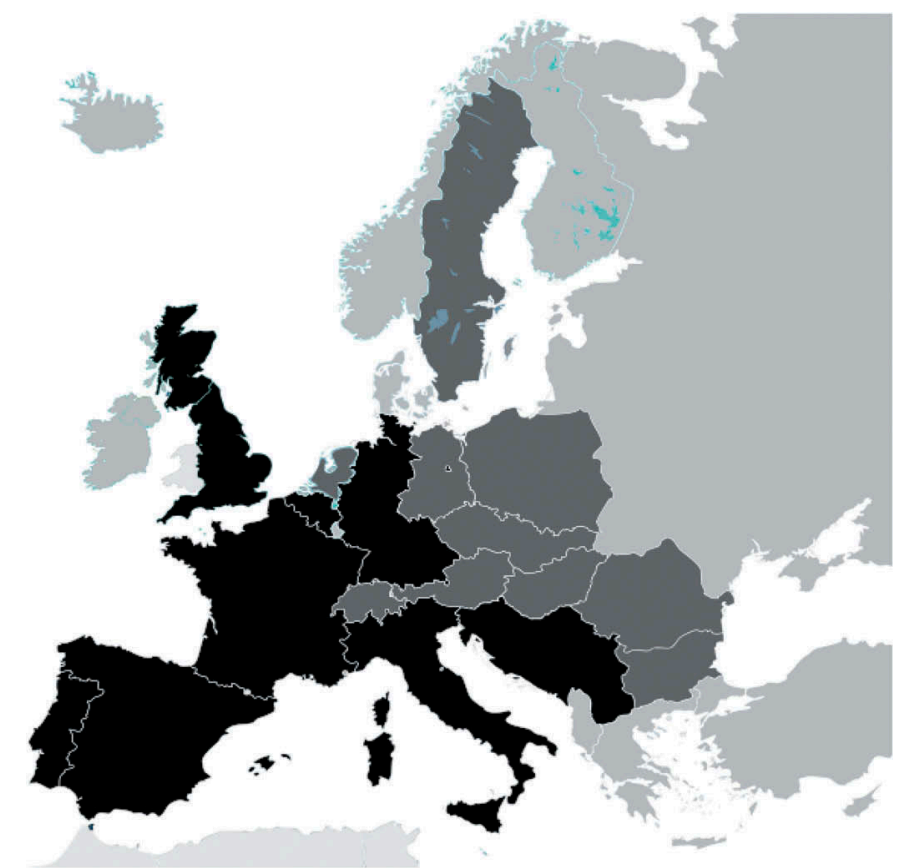

Map 6. National associations which participated in the first UEFA Cup. pale grey: associations which did not participate; grey: associations which participated with one club; dark grey: associations which had two clubs in the competition; black: associations that had between 3 and 4 clubs which took part in the competition.

\section{Conclusion: a future European Championship for the (big) clubs}

The aim of this article was to investigate the process of the establishment of the European scale in football through the lens of three major tournaments organized from the 1920s to the 1970s. I have argued that UEFA's creation was crucial in this process because they launched competitions that were truly European. I have shown that while the Mitropa cup was an important competition, it could not be placed on the same level with tournaments starting from the 1950s, viz. the European Champion Clubs' Cup and the UEFA Cup in regard to the number of countries involved and the link between these tournaments and the domestic leagues, two major criteria in the definition of a European tournament. The foundation of UEFA in the middle of the 1950s undoubtedly fostered this European turning point because the Union was the body that created and organized these championships (see Table 1).

Table 1. Summary.

\begin{tabular}{|c|c|c|c|c|c|}
\hline $\begin{array}{l}\text { Tournaments/ } \\
\text { Information }\end{array}$ & Organizers & $\begin{array}{l}\text { Year of } \\
\text { creation }\end{array}$ & $\begin{array}{l}\text { Numbers of national } \\
\text { associations involved } \\
\text { (in total) }\end{array}$ & $\begin{array}{c}\text { Maximum number of } \\
\text { clubs involved in } \\
\text { a year }\end{array}$ & Duration \\
\hline $\begin{array}{l}\text { Mitropa Cup (interwar } \\
\text { period) }\end{array}$ & Private & 1927 & 7 & 16 & $\begin{array}{l}\text { June to around } \\
\text { September/ } \\
\text { November }\end{array}$ \\
\hline ECCC & UEFA & 1955 & 33 & 33 & $\begin{array}{l}\text { From September } \\
\text { to May }\end{array}$ \\
\hline Fairs Cup/UEFA Cup & Private/UEFA & $\begin{array}{l}1955 / \\
1971\end{array}$ & 32 & 64 & $\begin{array}{l}\text { From September } \\
\text { to May }\end{array}$ \\
\hline
\end{tabular}

Source: www.rsssf.com 
During the 1970s and 1980s, the media gave greater importance to the European championships. Newspapers created special headlines and sometimes considered games played earlier in the domestic league as 'training' for the European battle. Furthermore, television began to broadcast more and more games in all European countries. Now the struggle for national supremacy was added to the struggle for European supremacy and Continental championships became events in which the history of the clubs came to be written (the renowned European epics). In 1979, the first volume of a comic series entitled Eric Castel (Ronnie Hansen in English) was published. It is interesting to note that the ultimate goal of Eric Castel - a French player who played notably for Barcelona FC and Paris Saint-Germain - and his trainers, his teammates and supporters of his team was to win the imaginary European trophy (CEVA cup). Thus, this comic series illustrated well the importance progressively accorded to the European scale in football. ${ }^{70}$

If playing in Europe appears self-evident nowadays, it is in fact the result of a long process which involved many actors (football administrators of national associations and clubs, journalists, and so on) and especially UEFA which regulated it and gave more legitimacy to European tournaments. Gradually, the European competitions reinforced the symbolic and economic power of UEFA that permitted it to reinforce its power on the regulation of the game. However, the establishment and development of the Champions League since the 1990s - which has undoubtedly been one of what journalists call the 'big-five' championships ${ }^{71}$ - has been a phenomenal global success. It is difficult to predict exactly the consequences of this hierarchical dominance for the future of European football. One way to address this anomaly may be to revoke the old idea - the creation of a separate European league for the big clubs. But then the very idea of a European scale would probably be in real jeopardy in the absence of the majority of countries from such a competition.

\section{Notes}

1. Quoted in Gasparini, 'Sport et football “européens”', 253.

2. Quin, 'La Coupe de l'Europe Centrale (1927-1938)'.

3. Mourlane, 'A Brief Moment of Latinity?'.

4. Breuil and Constantin, 'The Balkan Cups as a Vector of European Integration'.

5. See notbaly Vonnard, La Genèse de la Coupe des clubs champions. And for a summary: Vonnard, 'A Competition that Shook European Football'.

6. Kevin Tallec Marston has written several papers on this competition, see notably: "'Sincere camaraderie"'.

7. Mittag and Legrand, 'Towards a Europeanization of Football?'; Dietschy, 'L'euro de l'européisme à la commercialisation de la nation'.

8. Mittag, 'Europa und der Fussball'. Anthony King has also proposed a brief history of the Champions League (from the 1950s to the 1990s): King, The European Ritual, particularly the chapter 1.

9. Vonnard, 'How did UEFA Govern the European Turning Point in Football?'.

10. See for instance, Lanfranchi, 'Football, cosmopolitisme et nationalisme'.

11. Dietschy, 'Football during the Belle-Epoque', 40.

12. Ibid.

13. For an overview, see Macon, 'The Politicization of Football'; and Koller, 'Einlatung'.

14. Delépine, 'The Racing Clubs vs. Arsenal Matches, 1930-1962'.

15. Lanfranchi, 'Bologna'.

16. Dietschy, 'French Sport'.

17. Minutes of FIFA General Assembly of May 15 \& 26, 1928. Fédération Internationale de Football AssociationArchives (FIFAA), box: $12^{\text {th }}-19^{\text {th }}$ Ordinary Congress, 1923-1930, Activity Report Minutes. On the Creation of the World Cup, see Wahl, Histoire de la Coupe du monde de football.

18. Dietschy, 'Did a "Europe of Football" Exist in the 1930's ?', 521.

19. It is more an hypothesis than a real explanation and it would be necessary to conduct investigations on this change and more generally on the participation, or not, of the national associations in these two competitions.

20. Vonnard and Quin, 'Elément pour une histoire de la mise en place du professionnalisme dans le football suisse'.

21. Marschick, 'Mitropa'. If we follow the statistics furnished in the journal Libero (no. 34), the average per game for the year 1934 (when Mitropa was at this top level) was around 16'000. However, to understand what does this number mean, it would be necessary to compare it with the attendance in the Autrian, Czech, Italian and Hungarian leagues. 
22. Even when Swiss teams did not participate, Le Sport Suisse covered this event extensively. The competition was also covered in the Kicker. Furthermore, papers could be found in Belgian and Dutch sports journals (thanks to Xavier Breuil for this information).

23. Agenda of the Swiss National Football Association Executive Committee Meeting of November 14-15, 1936. Swiss National Football Association Archives (SNFAA), box (BD 79): Protokolle Fussball-Comité 1929-1937.

24. Quin, 'Central Europe Rules European Football'.

25. Mittag, 'Europa und der Fussball'.

26. From mid-1948 to mid-1952, no games between the Western and Eastern blocs were organized. Indeed, only Yugoslavia - which had a special status in the Soviet bloc after the Tito-Stalin split - played Western opponents during this period. On this point, see Mills, 'Cold War Football'.

27. Mourlane, 'A Brief Moment of Latinity?'.

28. 'La Coupe internationale des Grasshopper amorce d'un championnat d'Europe', France football, February 5, 1952.

29. 'Une Coupe européenne de football inter-clubs. V- La Mitropa Cup (ressuscitée) et le “Tournoi des foires" (envisagé) ne sont pas des obstacles à une compétition plus large', L’Equipe, March 12 \& 13, 1955.

30. Dietschy, 'The Superga Disaster and the Death of the "Great Torino"'.

31. See notably articles published in the Kicker (July 13, 1949) and in France Football (January 11, 1949 and July 1, 1952).

32. Vonnard, L'Europe dans le monde du football, 265-81.

33. 'La Coupe internationale a-t-elle vécu ? L'Italie n'aura pas terminé son programme l'an prochain', France football, April 19, 1949. See also a letter written by Barassi to the European national association before a meeting held in Zurich to discuss the reorganization of FIFA. Letter from O. Barassi to R. Seeldrayers, undated. FIFAA, box: Réorganisation 50-53. 1. Commission d'étude et bureau, folder: réorganisation 50/52.

34. Vonnard, La Genèse de la Coupe des clubs champions.

35. L'Equipe, December 15, 1954.

36. Montérémal, 'L'Equipe'.

37. During the 1955 General Assembly, the project of the European Championship for Nations was also rejected by the delegates.

38. Agenda of the UEFA Emergency Committee Meeting of May 8, 1955. Union of European Union Associations Archives (UEFAA), box (RM00000749): Executive Committee Meetings 1954-9.

39. Minutes of the UEFA Executive Committee Meeting of June 21, 1955. UEFAA, box (RM00000749): Executive Committee Meetings 1954-9.

40. General and Financial Report of the Secretary 1954-5. UEFAA, box (RM00000917): Reports of the Secretary 1954-89.

41. Finally, due to the lack of time, UEFA did not accept this request, but from the second European Champion Clubs' Cup these countries were invited to send their national champions.

42. General and Financial Report of the Secretary 1964-5. UEFAA, box (RM00000917): Reports of the Secretary 1954-89.

43. Marston, 'Sincere camaraderie'.

44. A situation that could create some trouble between the two bodies. On this problem, see Vonnard, L'Europe dans le monde du football (see 298-304 and 327-33).

45. EEEC Regulations 1956-7. UEFAA, box (RM00005391): Publication Department. European Champion Clubs' Cup. Règlements.

46. UEFA General Assembly Minutes of June 28-29, 1957. UEFAA, box (RM0005986): Founding Congress, 1954. I-III. Ordinary Congress, 1955-7.

47. Meyer, 'La fondation du "Grand Stade"'.

48. 'Le réseau européen de télévision', Bulletin de l'UER, January-February 35, no. 7 (1955), 172.

49. Minutes of the UEFA Executive Committee meetings of March 19, 1956. UEFAA, box (RM00000749): Executive Committee Meeting 1954-9.

50. 'Apothéose de la première Coupe d'Europe des clubs, ce soir, au Parc (20h30) devant 40.000 spectateurs et ... deux millions de téléspectateurs. Reims et Kopa sont plus alertes mais le Real Madrid a di Stefano!', L'Equipe, June 13, 1956.

51. On these negotiations, see Vonnard, 'Inventing a "European space of discussions".

52. EEEC Regulations 1968-9. UEFAA, box (RM00005391): Publication Department. European Champion Clubs' Cup. Règlements.

53. This percentage has been approximately calculated after a general reading of UEFA financial reports and budgets for the 1960s. However, it needs to be confirmed by further investigation.

54. The first European Champion Clubs' Cup gave a strong example of this possibility to bypass the Iron Curtain through football when UEFA managed to organize successfully a game between Real Madrid and Partizan Belgrade. In fact, the two countries had no diplomatic relations at that time (since 22 years previously), and the symbolic aspect of the game was clearly reinforced by the fact that these two clubs were the flagship football 
teams of their respective political regimes. Throughout the Cold War, around 30 per cent of all games were East-West matches. For a first reflection on this topic, Vonnard and Marston, 'Building Bridges between Separated Europeans'.

55. On this policy, see Mittag and Vonnard, 'The Role of Societal Actors in Shaping a Pan-European Consciousness'.

56. On these points, see Vonnard, 'Populariser davantage l'idée européenne par l'aide des sports'.

57. 'À la table ronde de Monaco. Lois du jeu et compétitions grands sujets de discussion', L’Equipe, March 11 \& 12, 1967.

58. Thommen was FIFA's vice-president while Barrasi was a member of the Executive Committee. As for Stanley Rous - who would become FIFA president in 1961 - he did not hold a position on the Executive Committee, yet he participated actively in the FIFA reorganization in the years between 1950 and 1953.

59. Rous, Football Worlds, 145-54.

60. 'Inter-Cities Fairs Cup. 1955-65'. UEFA, box (RM00003071): Fairs Cup, 1966-71.

61. However, the rules of the competition had to be sent each year to UEFA's Executive Committee in order to be approved.

62. Minutes of the Inter-Cities Fairs Cup Committee meetings on August 9, 1959. German State Archives (GSA), DY 12, Box (2.085): Zusammenarbeit mit der UEFA.

63. The competition was played in two distinct phases: a group stage (composed of three or four teams) and then the knock-out stage, i.e. semi-final and the final.

64. Ferran, 'La création', 22.

65. General and Financial Report of the Secretary 1966-7. UEFAA, box (RM00000917): Reports of the Secretary 1954-89.

66. Rules of the Inter-Cities Fairs Cup 1963/1964, art. 6. UEFAA, box (RM00002666): Regulations, Inter-Cities Fairs Cup, 1961-71.

67. In 1969, the delegates of the club of Basel requested the assembly to change the statutes so as to secure the presence of the founding members - like Basel - in the competition. Letter from P. Joris to the delegates of the clubs, June 5, 1969. UEFAA, box (RM00002666): Regulations, Inter-Cities Fairs Cup, 1961-71.

68. Minutes of the UEFA General Assembly Minutes of June 6, 1966. UEFAA, box (RM00000984): UEFA Congress, minutes, 1954-94.

69. Vonnard, 'Populariser davantage l'idée européenne par l'aide des sports'; Vonnard, 'Une ligue des champions avant l'heure?'.

70. Vonnard, 'Un grand match européen'.

71. England, France, Germany, Italy and Spain.

\section{Acknowledgments}

The author wants to thank the experts for their helpful comments; Shani D'Cruze for her proofreading of the text; and Souvik Naha for his strong support. This study was made during the author's postdoctoral research in Paris (LabEx Ehne) funded by the Swiss National Science Foundation (SNSF).

\section{Disclosure statement}

No potential conflict of interest was reported by the author.

\section{Bibliography}

Breuil, X., and N.P. Constantin. 'The Balkan Cups as a Vector of European Integration (1929-1994).' Sport History 35, no. 4 (2015): 591-603. doi:10.1080/17460263.2015.1073016.

Delépine, M. 'The Racing Clubs Vs. Arsenal Matches, 1930-1962: A Franco-British Ritual, European Games or Football Lessons?' Sport in History 35, no. 4 (2015): 604-617. doi:10.1080/17460263.2015.1073019.

Dietschy, P. 'The Superga Disaster and the Death of the "great Torino".' Soccer \& Society 5, no. 2 (2004): 298-310. doi:10.1080/1466097042000235272.

Dietschy, P. 'French Sport: Caught between Universalism and Exceptionalism.' European Review 19, no. 4 (2011): 509-525. doi:10.1017/S1062798711000160.

Dietschy, P. 'Did a “Europe of Football” Exist in the 1930's ?' Sport in History 35, no. 4 (2015): 521. doi:10.1080/ 17460263.2015.1071082. 
Dietschy, P. 'Football during the Belle-Epoque: The First “Europe du Football” (1903-1914).' in Building Europe with the Ball. Turning Points in the Europeanization of Football (1905-1995), ed. P. Vonnard, G. Quin, and N. Bancel, 21-51. Oxford: Peter Lang, 2016.

Dietschy, P. 'L'euro de l'européisme à la commercialisation de la nation.' Pôle Sud 47, no. 2 (2017): 25-39.

Ferran, J. 'La Création.' in L'Equipe: 50 ans de Coupe d'Europe, ed. P.-M. Descamps, J. Hennaux, and B. Didier, $10-26$. Paris: L’Equipe, 2005.

Gasparini, W. 'Sport et football 'européens'. Genèse d'une nouvelle catégorie de l'action publique.' in $L$ 'Europe du football. Socio-histoire d'une construction européenne, ed. W. Gasparini, 25-49. Strasbourg: Presses universitaires de Strasbourg, 2017.

Hare, G. 'What Is an International Match? French Football Clubs and the Earliest "International Matches"'. Sport in History 35, no. 4 (2015): 497-514. doi:10.1080/17460263.2015.1071081.

King, A. The European Ritual. Football in the New Europe. Aldershot: Ashgate, 2003.

Koller, C. 'Einlatung: Europäischer Fussball Im zeithaler der Katastrophen.' in Fussball Zwischen Den Kriegen, ed. C. Koller and F. Brändle, 1-22. Zurich: Lit Verlag, 2010.

Lanfranchi, P. 'Bologna: “The Team that Shook the World”.' The International Journal of the History of Sport 8, no. 3 (1991): 336-346. doi:10.1080/09523369108713766.

Lanfranchi, P. 'Football, cosmopolitisme et nationalisme.' Pouvoir 101 (2002): 15-25. doi:10.3917/pouv.101.0015.

Macon, B. 'The Politization of Football: The European Game and the Approach to the Second World War.' Soccer and Society 9, no. 4 (2007): 532-555.

Marschick, M. 'Mitropa: Representations of “central Europe” in Football.' International Review for the Sociology of Sport 36, no. 7 (2001): 7-23. doi:10.1177/101269001036001003.

Marston, K.T. "Sincere Camaraderie": Professionalization, Politics and the Pursuit of the European Idea at the International Youth Tournament, 1948-57.' in Building Europe with the Ball. Turning Points in the Europeanization of Football (1905-1995), ed. P. Vonnard, G. Quin, and N. Bancel, 137-161. Oxford: Peter Lang, 2016.

Meyer, J.-C. 'La fondation du "Grand Stade". De la triomphale retransmission en direct de la Coupe du monde 1954 et de ses avatars dans les pays membres de l'eurovision (1954-1958).' Traverse. Revue d'histoire 23, no. 1 (2016): 49-59.

Mills, R. 'Cold War Football: Soviet Defence and Yugoslav Attack following the Tito-Stalin Split of 1948.' Europe-Asia Studies 68, no. 10 (2016): 1736-1758. doi:10.1080/09668136.2016.1243228.

Mittag, J. 'Europa und der Fussball. Die Europäische Dimension des Vereinsfussballs vom mitropa-cup bis zur Champions League.' in Das Spiel mit dem Fussball. Interessen, Projektionen und Vereinnahumungen, ed. J. Mittag and J.-U. Nieland, 155-176. Essen: Klartext, 2007.

Mittag, J., and B. Legrand. 'Towards a Europeanization of Football? Historical Phases in the Evolution of the UEFA Football Championship.' Soccer \& Society 11, no. 6 (2010): 709-722. doi:10.1080/14660970.2010.510727.

Mittag, J., and P. Vonnard. 'The Role of Societal Actors in Shaping a Pan-European Consciousness. UEFA and the Overcoming of Cold War Tensions, 1954-1959.' Sport in History 37, no. 3 (2017): 332-352. doi:10.1080/ 17460263.2017.1358659.

Montérémal, G. 'L'Equipe: médiateur et producteur de spectacle sportif (1946-1967).' Le Temps des Médias 9 , no. 2 (2007): 107-120. doi:10.3917/tdm.009.0107.

Mourlane, S. 'A Brief Moment of Latinity? France, Italy and the Latin Cup 1949-1957.' Sport History 35, no. 4 (2015): 580-590. doi:10.1080/17460263.2015.1073014.

Quin, G. 'La Coupe de l'Europe Centrale (1927-1938), une compétition internationale oubliée?' Stadion. Revue Internationale d'Histoire du Sport 37, no. 2 (2013): 285-304.

Quin, G. 'Central Europe Rules European Football. The "golden Age” of Regional Connections in European Football (1926-38).' In Building Europe with the Ball. Turning Points in the Europeanization of Football (1905-1995), ed. P. Vonnard, G. Quin, and N. Bancel, 53-73. Oxford: Peter Lang, 2016.

Rous, S. Football Worlds. A Lifetime in Sport. London: Faber, 1978.

Vonnard, P. La genèse de la coupe des clubs champions. une histoire du football européen. Neuchâtel: CIES, 2012.

Vonnard, P. 'A Competition that Shook European Football: The Origins of the European Champion Clubs' Cup, 1954-1955.' Sport in History 34, no. 4 (2014): 595-619. doi:10.1080/17460263.2014.901236.

Vonnard, P. 'How Did UEFA Govern the European Turning Point in Football? UEFA, the European Champion Clubs' Cup and the Inter-Cities Fairs Cup Projects (1954-1959).' In Building Europe with the Ball. Turning Points in the Europeanization of Football (1905-1995), ed. P. Vonnard, G. Quin, and N. Bancel, 165-186. Oxford: Peter Lang, 2016.

Vonnard, P., and K.T. Marston. 'Building Bridges between Separated Europeans: The Role of UEFA's Competitions in East-West Exchanges (1955-1964).' In Beyond Boycotts. Sport during the Cold War in Europe, ed. P. Vonnard, N. Sbetti, and G. Quin, 85-109. Oldenburg: De Gruyter, 2018.

Vonnard, P. L'Europe dans le monde du football. Genèse et formation de l'UEFA (1930-1960). Brussels: Peter Lang, 2018. 
Vonnard, P. “'Populariser davantage l'idée européenne par l'aide des sports. La CEE”, l'UEFA et le projet de Coupe du Marché commun en football (1966-1968).' Journal of European Integration History 24, no. 2 (2019a): 353-370. doi:10.5771/0947-9511-2018-2-353.

Vonnard, P. 'Une ligue des champions avant l'heure? L'UEFA face au projet de la Coupe Télé-Magazine.' Sciences Sociales Et Sport 13, no. 1 (2019b): 113-136. doi:10.3917/rsss.013.0113.

Vonnard, P. 'Inventing a "European Space of Discussions". UEFA-EBU Interrelationships, C. 1950s -1970s.' in Beyond Brussels. Reassessing European Integration in East and West Europe, ed. M. Broad and S. Kansikas, Basingstoke: Palgrave MacMillan, forthcoming.

Vonnard, P. "Un grand match européen". La Coupe Ceva dans la bande dessinée Eric Castel: un témoin de l'européanisation du football ? European Studies in Sport History 11 (Forthcoming): 127-147.

Vonnard, P., and G. Quin. 'Elément pour une histoire de la mise en place du professionnalisme dans le football suisse: processus, résistances et ambiguïtés.' Revue suisse d'histoire 62, no. 1 (2012): 70-85.

Wahl, A. Histoire de la coupe du monde de football. Une mondialisation réussie. Brussels: P.I.E. Peter Lang, 2013. 